\title{
Korelasi antara Kebersyukuran Terhadap Kecemasan Menghadapi Persalinan Pada Ibu Hamil Trimester Tiga di Banjarmasin
}

\author{
Umi, Mubarak \\ Universitas Islam Negeri Antasari Banjarmasin \\ Email: ummisaman7@gmail.com \& mubarak@iain-antasari.ac.id
}

\begin{abstract}
Abstrak
Penelitian dilatarbelakangi oleh kecemasan yang dialami ibu hamil trimester tiga. Jika kecemasan yang dialami tidak teratasi, maka akan mengganggu kesehatan ibu hamil baik fisik maupun psikologis serta mengganggu kesehatan bayi. Kebersyukuran merupakan salah satu cara mengalihkan individu dari keadaan psikologis yang negatif menjadi psikologis yang positif. Peneliti ingin mengetahui bagaimana pengaruh kebersyukuran terhadap kecemasan serta seberapa besar tingkat kebersyukuran dan kecemasan yang dialami ibu hamil trimester tiga.. Subjek penelitian adalah ibu hamil trimester tiga sebanyak 60 orang di Kota Banjarmasin. Hasil penelitian menunjukkan bahwa ada hubungan signifikan antara kebersyukuran terhadap kecemasan ibu hamil trimester tiga. Arah hubungan variabel kebersyukuran $(\mathrm{x})$ dan variabel kecemasan $(\mathrm{y})$ yaitu negatif, semakin tinggi nilai $r$ variabel $x$, maka nilai $r$ variabel y akan semakin rendah. Besarnya pengaruh kebersyukuran terhadap kecemasan adalah -0,772 (59,6\%).
\end{abstract}

Kata kunci: kebersyukuran, kecemasan, ibu hamil trimester tiga

\section{Correlation between Being Gratitude and Anxiety Facing Birth In Pregnant Women Trimester Three in Banjarmasin}

\begin{abstract}
This research is conducted because the indication of pregnant women's anxiety in the last trimester. This anxiety is caused by some factors, either internal or external. If the subject's anxiety cannot be solved, it will impact the health of the subject, both psychical and psychological, even effect the health of the unborn baby. Gratitude is one way to change a negative psychological condition to a positive one. In this study, the researcher wants to identify how gratitude will effect some pregnant women's anxiety so that the data about that can be analyzed to find out the level of gratitude and the anxiety endured by the pregnant women in the last trimester. The research subjects were 60 (sixty) pregnant women in the last trimester in Banjarmasin. The results showed that there is a significant relationship between gratitude and pregnant women's anxiety. The correlation of the variable of gratitude $(x)$ to the variable of the anxiety $(y)$ tends to be negative. Then, the higher the $r$ score of $x$ variable, the lower the $r$ score of $y$ variable. The significant impact of gratitude toward the anxiety is $-0,772$ or 59,6 .
\end{abstract}

Keywords: gratitude, anxiety, pregnant women

\section{Pendahuluan}

Masa kehamilan merupakan masa dimana tubuh seorang ibu hamil mengalami perubahan fisik dan perubahan psikologis akibat peningkatan hormon kehamilan. Selama masa kehamilan terjadi penambahan hormon estrogen sebanyak sembilan kali lipat dan progesterone sebanyak dua puluh kali lipat yang dihasilkan sepanjang siklus menstruasi normal. Adanya perubahan hormonal ini menyebabkan emosi wanita selama kehamilan cenderung berubah-ubah, sehingga tanpa ada sebab yang jelas seorang wanita hamil merasa sedih, mudah tersinggung, marah atau justru sebaliknya merasa sangat bahagia (Diani \& Susilawati, 2013).

Sikap ibu saat masa kehamilan dapat mempengaruhi bayinya yang belum dilahirkan. Hal ini akibat adanya perubahan endokrin yang dapat terjadi apabila calon ibu menderita tekanan yang berat dalam waktu yang lama. Sebaliknya sikap yang menyenangkan akan menimbulkan keseimbangan tubuh yang baik dan hal ini akan menunjang perkembangan yang normal sepanjang periode kehamilan. Pengaruh menyenangkan dan tidak menyenangkan tidak tergantung 
pada satu anggota keluarga saja, tapi sikap semua anggota keluarga. Apabila sikap menyenangkan pada bayi yang dikandung, bisa dipastikan mapan dan begitu pula sebaliknya (Hurlock, 2012).

Semakin bertambah beratnya beban kandungan dan bertambah banyaknya rasa tidak nyaman secara fisik, maka kondisi psikologis ibu hamil juga ikut terganggu, sehingga dapat mengalami kecemasan. Di samping itu kehamilan tersebut mengandung resiko mempertaruhkan jiwa dan raga, khususnya pada saat melahirkan. Karena itu kehamilan dan melahirkan merupakan suatu perjuangan yang berat bagi setiap wanita, yang tidak lepas dari kecemasan dan kesakitan (Kartono, 192).

Kecemasan merupakan campuran beberapa emosi tidak menyenangkan yang didominasi oleh ketakutan yang tak terkendali terhadap kondisi mengancam yang kondisinya mengarah kepada hal-hal yang belum tentu akan terjadi. Maher menjelaskan mengenai komponen kecemasan yaitu emosional, kognitif, dan psikologis (Sobur, 2013), selanjutnya dalam sumber lain disebutkan komponen kecemasan yaitu psikologis dan fisiologis (Maimunah, 2012).

Menurut Karen Horney tentang sebab terjadinya cemas ada yaitu tidak adanya kehangatan dalam keluarga dan adanya perasaan diri yang dibenci, tidak disayangi dan dimusuhi atau disaingi. Berbagai bentuk perlakuan yang diterapkan dalam keluarga, misalnya sikap orang tua yang otoriter, keras, ketidakadilan, pengingkaran janji, kurang menghargai satu sama lain, dan suasana keluarga yang penuh dengan pertentangan dan permusuhan. Lingkungan yang penuh dengan pertentangan dan kontradiksi, yakni adanya faktor yang menyebabkan tekanan perasaan dan frustasi, penipuan, pengkhianatan, kedengkian, dan sebagainya (Darajat, 1993).

Kecemasan seringkali merampas kenikmatan dan kenyamanan hidupnya, serta membuat mereka selalu gelisah dan tidak bisa tidur lelap sepanjang malam. Ada beberapa hal yang selalu menyebabkan situasi tersebut terjadi di antaranya lemahnya keimanan dan kepercayaan terhadap Allah, kurangnya tawakkal mereka terhadap Allah, terlalu sering memikirkan kejayaan masa depannya dan apa yang akan terjadi kelak dengan pola pikir dan cara pandang yang negatif terhadap dunia dan seisinya, rendahnya permohonan mereka tentang tujuan dari penciptaan mereka, selalu tergantung pada diri sendiri dan sesama manusia lain dalam urusan di dunia, sehingga lupa menggantungkan hidupnya kepada Allah, mudah dipengaruhi oleh hawa nafsu ketamakan, keserakahan, ambisi, keegoisan yang berlebihan, meyakini bahwa keberhasilan berada di tangan manusia sendiri atau ditentukan oleh usahanya sendiri (Al Husain, 2004).

Banyak penelitian menunjukkan bahwa ibu hamil sering kali mengalami kecemasan, terlebih pada kehamilan trimester ketiga. Berdasarkan penelitian yang dilakukan oleh Luh Putu Prema Diani dan Luh Kadek Pande Ary Susilawati, kecemasan pada ibu hamil biasanya disebabkan oleh kurangnya dukungan dari suami, baik itu dukungan secara sosial maupun psikologis (Diani \& Susilawati, 2013). Kecemasan pada ibu hamil dipengaruhi oleh graviditas dan tingkat pendidikan sedangkan menurut Margiantari, Heru Basuki, dan Mentari Ayu Ningsih faktor yang mempengaruhi kecemasan pada ibu hamil berasal dari faktor internal, seperti pemikiran subyek dan harapan-harapan yang dimilikinya dan faktor eksternal mencakup keluarga, seperti suami, orang tua dan kerabat dekat. Serta lingkungan sekitar seperti teman, tetangga, tempat bekerja, adat istiadat, tradisi dan budaya (Astria, dkk., 2008).

Kebersyukuran merupakan salah satu faktor yang sangat berperan dalam menciptakan suasanan hati tenang dan bahagia. Kebersyukuran atau gratitude adalah faktor yang dapat memunculkan kesejahteraan atau ketentraman pada psikologis dikarenakan dia mampu mengatasi kerentanan pada emosi individu, dimana pada saat memasuki masa kehamilan individu yang memiliki kebersyukuran yang tinggi tentunya telah menerima dan memahami keadaan dirinya dengan matang. Hal tersebut dikarenakan kebersyukuran akan menghasilkan kesejahteraan melalui 
kombinasi refleksi, emosi positif dan perilaku sosial yang adaptif (William. E. Breen, Todd B. Kashdan, Monica L. Lenser, dan Frank D. Fincham, 2010).

Kebersyukuran adalah berterima kasih kepada Allah, lega, senang, dan menyebut nikmat yang diberikan kepadanya dimana rasa senang dan lega itu terwujud dalam lisan, hati, dan perilaku serta taat kepada Allah dengan berbagai taqarrub, lahir maupun batin dan terima kasih kepada Allah atas segala nikmat yang dilimpahkan-Nya (McCullough, 2010).

Fitzgerald dalam R. A. Emmons dan M.E Mccullough dalam psychology of Gratitude mengidentifikasi tiga komponen dari kebersyukuran yaitu a warm sense of appreciation, a sense of goodwill, and a disposition to act (McCullough, 2010). Selanjutnya menurut al-Ghazali kompenen kebersyukuran yaitu hati, lisan, dan perbuatan.

Berdasarkan penelitian terdahulu, peneliti merumuskan hipotesis: terdapat hubungan negatif antara kebersyukuran dengan kecemasan jika semakin tinggi kebersyukuran maka akan semakin rendah kecemasan. Begitu juga sebaliknya, semakin rendah kebersyukuran maka akan semakin tinggi juga kecemasan.

\section{Metode}

\section{Partisipan}

Penelitian ini menggunakan pendekatan kuantitatif korelasional. Subyek penelitian ini adalah ibu hamil menjelang melahirkan, yaitu ada pada periode kehamilan trimester ketiga dengan usia kehamilan dari 6 bulan hingga sebelum melahirkan. Jumlah sampel pada penelitian ini yaitu 60 orang dengan teknik pengambilan sampel purposive quota sampling.

\section{Pengukuran}

Instrumen yang digunakan dalam penelitian terdiri dari dua skala yaitu skala kebersyukuran dan skala kecemasan.Skala dengan model skala Likert pernyataan yang disediakan sebanyak 4 pilihan yaitu sangat setuju (SS), Setuju (S), tidak setuju (TS) dan sangat tidak setuju (STS). skala kebersyukuran terdiri dari 29 aitem dengan reliabilitas Cronbach Alfa 0,766 sementara skala kecemasan terdiri dari 32 aitem dengan dengan reliabilitas Cronbach Alfa 0,747.

\section{Hasil}

Hasil analisis menunjukkan bahwa korelasi kebersyukuran dengan tingkat kecemasan pada ibu hamil trimester tiga sebesar $r$ $=-0,772$. Level Signifikansi 0,0000, maka dapat disimpulkan bahwa ada hubungan negatif yang kuat antara variabel $x$ (kebersyukuran) dengan variabel y (kecemasan). Hal ini berarti semakin tinggi kebersyukuran, maka semakin rendah kecemasan menghadapi persalinan.

\section{Pembahasan}

Hasil penelitian ada hubungan negatif yang signifikan antara tingkat kebersyukuran dengan tingkat kecemasan pada ibu hamil trimester tiga. Hasil ini sesuai dengan apa yang dikemukakan oleh Emmons, dan McCullough (2004) dan al-Ghazali (2000) yang menjelaskan tentang pengaruh kebersyukuran terhadap psikologis individu.

Menurut Emmons, dan Mc Cullough (2004) kebersyukuran merupakan sifat yang sangat penting. Kebersyukuran merupakan salah satu dari emosi dasar yang diperlukan untuk stabilitas individu. Mengungkapkan rasa syukur baik itu terhadap manusia dalam bentuk terima kasih dan kepada Tuhan dalam bentuk syukur yang lebih tinggi merupakan suatu kebijakan yang telah diakui secara universal.

Individu yang di dalam dirinya terdapat kebersyukuran, maka individu tersebut akan menghargai orang-orang yang berada di sekitarnya. Orang-orang yang berada di sekitarnya ini bisa dalam ranah keluarga atau ranah masyarakat. Individu dalam hal ini yaitu ibu hamil trimester tiga yang memiliki kebersyukuran, maka individu tersebut akan lebih menghargai anak yang ia kandung, menghargai suami, dan seluruh keluarganya serta orang-orang yang berada di sekitarnya. 
Selanjutnya individu yang memiliki kebersyukuran selalu memiliki keinginan yang baik. Keinginan yang baik berasal dari pemikiran yang positif dan hati yang selalu menyangka baik (huznuzhon) terhadap segala sesuatu yang individu tersebut hadapi. Selanjutnya hal tersebut juga akan menjadikan individu memiliki kecenderungan untuk bertindak positif. Psikologis individu yang positif akan menjauhkan individu dari kondisi psikologis yang negatif.

Selanjutnya menurut Ghazali (2000) kebersyukuran yang ada dalam diri individu akan diimplemantasi dalam diri individu tersebut adalam bentuk perasaan-perasaan dan daya emosi yang khas dan kuat. Hal ini akan menjadikan psikologis individu kuat dan emosi individu tersebut menjadi lebih stabil. Emosi yang stabil akan tercermin dengan timbulnya rasa puas, rasa gembira, dan pengakuan terhadap nikmat yang telah diterima. Sebagaimana yang dijelaskan pada paparan terdahulu, bahwa psikologis ibu hamil sangat fluktuatif dari emosi positif ke emosi negatif dan sebaliknya. Kehamilan merupakan masa dimana tubuh seorang ibu hamil mengalami perubahan fisik dan perubahan psikologis akibat peningkatan hormon kehamilan. Selama masa kehamilan terjadi penambahan hormon estrogen jebanyak sembilan kali lipat dan progesteron sebanyak dua puluh kali lipat yyang dihasilkan sepanjang siklus menstruasi normal. Adanya perubahan hormonal ini menyebabkan emosi wanita selama kehamilan cenderung berubah-ubah, sehingga tanpa ada sebab yang jelas seorang wanita hamil merasa sedih, mudah tersinggung, marah atau justru sebaliknya merasa sangat bahagia. Daya emosi yang kuat akan menjadikan individu lebih mudah mengendalikan emosinya.

Individu yang memiliki kebersyukuran akan menampakan kebersyukuran dengan puji-pujian yang ditujukan kepada Allah. Puji-pujian yang ditujkan kepada Allah akan memberi dampak relaksasi bagi ibu hamil. Keadaan yang tenang akan dapat mencegah individu dari keadaan mood yang negatif.

Beberapa penelitian telah menunjukan hubungan antara coping religius dengan kecemasan yang turut menunjukan pentingnya unsur spiiritual dan religius dalam penanganan kecemasan. Berdasarkan penelitian tersebut, terdapat hubungan yang signifikan antara kebersyukuran dengan depresi. Semakin seseorang bersyukur maka akan semakin rendah tingkat depresinya. Begitu pula terhadap kecemasan dan stres, semakin tinggi tingkat kebersyukuran seseorang, maka akan semakin rendah tingkat kecemasan dan stresnya. Konsekuensi alami dari kehidupan didasarkan pada perilaku prososial dan bergerak menuju kesempurnaan dan ideal. Kebersyukuran memberi makna hidup pada individu ada faktor-faktor yyang diketahui berkaitan dengan depresi, kecemasan, stres dan kepuasan hidup termasuk adaptasi sosial dan dukungan sosial. Kebersyukuran imemiliki hubungan dengan interpretasi positif, adaptasi aktif, memberi dukungan sosial emosional serta motivasi sosial. Mengekspresikan kebersyukuran dapat menjadi motivasi moral dan meningkatkan suasana hati yang positif di masa depan." Terdapat perbedaan selisih skor kecemasan pretest dan posttest yang signifikan pada kelompok eksperimen dan kelompok kontrol. Hal ini imenunjukkan bahwa intervensi berupa pelatihan relaksasi dengan dzikir terbukti dapat menurunkan kecemasan kehamilan subjek penelitian. Penelitian tersebut juga menunjukan hasil yang signifikan antara kebersyukuran terhadap kesejaahteraan psikologis, semakin tinggi kebersyukuran seseorang, maka akan semakin tinggi pula kesejahteraan psikologisnya, begitu pula sebaliknya.

Kebersyukuran akan membawa individu untuk menggunakan segala nikmat dalam ketaatan. Menggunakan nikmat dalam ketaatan akan membawa individu untuk selalu berperilaku positif dan adaptif. Dengan demikian akan menghadirkan suasana psikologis yang positif pula. Selain kehamilan itu adalah anugerah, jika individu memiliki kriteria-kriteria kebersyukuran tersebut, tentu kecemasan yang dialami akan teratasi.

Hasil penelitian ini juga menguatkan penelitian-penelitian sebelumnya yang telah membuktikan bahwa terapi berbasis keyakinan agama yang dimiliki dapat mem- 
bantu meningkatkan kesehatan mental sesorang. Penelitian ini menunjukkan bahwa kebersyukuran terbukti dapat meningkatkan kesehatan mental dengan cara mengurangi kecemasan subjek. Bedanya, penelitian ini mengkhususkan subjek pada ibu hamil. Penelitian ini menambahkan fakta bahwa pendekatan berbasis keislaman juga dapat membantu menurunkan kecemasan ibu hamil menjelang melahirkan.

Kebersyukuran merupakan suatu teori yang telah lama dan mapan dalam keilmuan islam, namun masih tergolong baru dalam dunia psikologi. Kebersyukuran merupakan suatu perilaku yang penuh kebaikan dan rasa hormat serta mengagungkan atas segala nikmat yang telah diberikan oleh Allah dalam rangka mendekatkan diri kepada Allah.

Kebersyukuran merupakan salah satu faktor yang sangat berperan dalam menciptakan suasana hati tenang dan bahagia. Kebersyukuran adalah faktor yang dapat memunculkan kesejahteraan atau ketentraman pada psikologis dikarenakan dia mampu mengatasi kerentanan pada emosi individu, dimana pada saat memasuki masa kehamilan individu yang memiliki kebersyukuran yang tinggi tentunya telah menerima dan memahami keadaan dirinya dengan matang. Hal tersebut dikarenakan kebersyukuran akan menghasilkan kesejahteraan melalui kombinasi refleksi, emosi positif dan perilaku sosial yang adaptif. Menurut Karen Horney, kecemasan bisa disebabkan oleh tidak ada kehangatan dalam keluarga, sikap negatif dari keluarga, dan lingkungan yang penuh kontradiksi. Selanjutnya menurut Musfir bin Said az-Zahrani, kecemasan dipengaruhi oleh keadaan keluarga yang tidak kondusif, lingkungan yang penuh persaingan, dan rendahnya tingkat pendidikan serta spiritualitas.

Manusia mengalami kecemasan saat mereka sadar bahwa eksistensinya terancam hancur atau rusak dan ia dapat menjadi 'bukan apa-apa' (nothing). TTidak ada seorang pun yang dapat menghindari dampak dari kecemasan, karena dalam melalui masa pertumbuhan manusia akan mengalami kecemasan yyang normal. Dalam hal ini pengala- man melahirkan sebelumnya yang kurang menyenangkan atau informasi kesehatan saat ini yang akan berpengaruh negatif terhadap proses melahirkan nanti. Kecemasan adalah hal yang normal jika itu terjadi secara proporsional. Namun jika kecemasan terus berlarut dan tidak proporsional imaka akan menjadikan pelakunya neurotik atau sakit. Kecemasan neurotik sebagai reaksi yang tidak proporsional atas suatu ancaman, meliputi represi dan bentuk-bentuk lain dari konflik intrapsikis. Oleh karena itu diperlukan penenganan yang menyeluruh yaitu secara medis dan psikologis.

Jika ditinjau dari sudut kecemasan sebagai respon, maka subjek berada pada respon state anxiety yaitu kecemasan yang timbul jika individu dihadapkan pada situasisituasi tertentu yang menyebabkan individu mengalami kecemasan dan gejalanya selalu tampak selama situasi itu ada. Respon ini berasal dari jenis kecemasan objektif, dimana subjek mengalami kecemasan yang disebabkan oleh faktor yang dapat diamati dan situasi yang memang secara logika dapat membayakan terhadap keselamat ibu dan bayi.

Kebersyukuran merupakan energi positif yang dapat mengatasi permasalahan. Rasa syukur dapat membantu seseorang untuk menjadi lebih peduli pada diri sendiri yang kemudian akan berdampak pada pembinaan hubungan baik dengan orang lain. Kebersyukuran merupakan salah satu cara untuk mengalihkan konsentrasi dari situasi negatif dan kemudian diarahkan pada situasi yang baik. Oleh karena itu, kondisi psikologis yang patologis seperti cemas akan bisa teratasi dengan kebersyukuran.

\section{Kesimpulan}

Berdasarkan hasil uji hipotesis didapatkan hasil hubungan negatif yang signifikan $(\operatorname{Rxy}=-0,772$; sig $=0,000<0,01)$ antara kebersyukuran dengan kecemasan. Hal ini menunjukan bahwa kebersyukuran memiliki hubungan yang sangat kuat dengan kecemasan ibu hamil. 


\section{Daftar Pustaka}

Anwar, Rosihon. (2010). Akhlak Tasawuf. Bandung: Pustaka Setia,

Anwar, Saifuddin. Metode Penelitian. Yogyakarta: Pustaka Pelajar, 1998.

Asarie, Sukmadjaya dan Rosy Yusuf.(1984) Indeks Alquran. Bandung: Pustaka,

Asghari, Basri lba. (1994) Solusi al-Quran: Problematika Sosial, Politik, dan Budaya. Jakarta: Rineka Cipta,

Astria, Yonne Irma Norbaeti, dan Catur Rosidati, (2008) "Hubungan Karakteristik Ibu Hamil Trimester III dengan Kecemasan dalam Menghadapi Persalinan Di Poliklinik Kebidanandan Kandungan Rumah Sakit X Jakarta", Jurnal Universitas Padjadjaran, Volume 10 No. XIX, 3848.

Azwar, Saifuddin. (2003). Metode Penelitian. Yogyakarta: Pustaka Pelajar,. . (2010) Penyusunan Skala Psikologi. Yogyakarta: Pustaka Pelajar,

Barlow, David H. (2004) Anxiety and Its Disorder: The Nature and Treatment of Anxiety and Panic. New York: The Guilford Press,

Breen, William. E. (2010) "Gratitude and forgiveness: Convergence and divergence on self report and informant ratings. Personality and Individual Differences," Article George Mason University, 4400 University Drive, Fairfax, VA 22030, United States and Florida State University, United States, 2010.

Bustaman, Hanna Djumhana. (2001). Integrasi Psikologi dengan Islam: Menuju Psikologi Islami. Yogyakarta: Pustaka Pelajar Offset, 2001.

Chaplin, J.P. (2001). Kamus Psikologi. Terj. Kartini Kartono. Jakarta: PT. Raja Grafindo Persada, Cet. VII,

Clerg, Linda De.(1994) Tingkah Laku Abnormal: Dari Sudut Pandang Perkembangan,. Jakarta: PT. Grasindo, 1994.

Colman, Andrew M. (2003) Oxford Dictionary of Psychology. New York: Oxford
University Press,

Daradjat, Zakiyah.(1993) Kebahagiaan. Bandung: CV Ruhama, 1993.

Diani, Luh Putu Prema dan Luh Kadek Pande Ary Susilawati. (2013) "Pengaruh Dukungan Suami terhadap Istri yang Mengalami Kecemasan pada Kehamilan Trimester Ketiga Di Kabupaten Gianyar". Jurnal Psikologi Udaya, Vol. 1, No. 1,

Dinas Kesehatan Kota Banjarmasin.(2015) Laporan Tahunan Dinas Kota Banjarmasin Tahun 2015. Banjarmasin: Dinkes,

Emmons, Robert A.\& Michael E. McCullough. (2004) The Psychology of Gratitude: Series in Affective sciense. New York: Oxfort University Press,.

Emmons, Robert A.(2007) Thanks!: How the New Science of Gratitude can Make You Happier. New York: Houghton Mifflin Company

Faizah, Siti. (2003) "Syukur dalam Alquran" Skripsi tidak diterbitkan, Fakultas Ushuluddin dan Humaniora, IAIN Antasari, Banjarmasin.

Fauziyah, Fitri dan Julianti Widuri. (2005). Psikologi Abnormal Klinis Dewasa. Jakarta, UII Press,

Feist, Jess dan Gregory J. Feist, (2009) Theories of Personality. Terj. Smita Prathita Sjahputri dengan judul Teori Kepribadian. Jakarta: Salemba Humanika,

Furchon, Arief. (1982) Pengantar Penelitian dalam Pendidikan. Surabaya: Usaha Nasional, .

G, Bono, Emmons, R.A, McCullough, M.E. (2004) Gratitude In Practiced And The Praticed Of Gratitude. In P.A. Linsey \& S. Joseph. Positive Psychology In Practice. Hoboken NJ, US; John Wiley \& Sun Inc,

Gaspersz, Vincent.(1989) Statistik. Bandung: CV. Amico,

Ghazali, Al. Mukhtatashar Ihya' Ulumuddin, (2000) Terj. Irwan Kurniawan dengan judul Mutiara Ihya Ulumuddin: Ringkasan yang Ditulis Sendiri Oleh Sang Hujjatul Islam. Bandung: 
PT. Mizan,

Halgin, Ricard $P$ dan Susan Krauss Whitbourne. (2010) Abnormal Psychology: Clinical Perspectives on Psychologycal Disorder, Terj. Aliya Tusyani dkk dengan judul Psikologi Abnormal Persfektif Lkinis Gangguan Psikologis. Jakarta: Salemba Humanika,

Hawari, Dadang (2001) Manajemen Stress, Cemas dan Depresi. Jakarta : FK UI,

Hay, Louise L. at all (2008). Gratitude a Way of Life. tt: Accessible Publishing Systems,

Hurlock, Elizabeth B.(2012) Development Psychology: A life Span Approach, Terj. Istiwidayanti dan Soedjarwo dengan judul Psikologi Perkembangan. Jakarta: Erlangga,

Jauziah, Ibn Qoyyim Al (1998). Fawa'idul Fawaid, Terj. Kathur Suhardi dengan judul Mendulang Faedah dari Lautan IImu. Jakarta: Pustaka al-Kautsar, 1998.

Kartono, Kartini (2003) Patologi Sosial 3: Gangguan-gangguan Kejiwaan (Jakarta: CV. Rajawali, Cet. III. .(1992) Psikologi Wanita: Mengenal sebagai Ibu dan Nenek. Bandung: Mandar Maju.

Langgulung, Hasan (1992) Kesehatan Mental. Jakarta: PT. Mutiara Sumber Widya Offset, (1992).Teori-teori Kesehatan Mental. Jakarta: PT. Mutiara Sumber Widya Offset Jakarta,

Maimunah, Annisa dan Sofia Retnowati, (2011). Pengaruh Pelatihan Relaksasi dengan Dzikir untuk Mengatasi Kecemasan Ibu Hamil Pertama", Jurnal Psikologi Islam (JPI): Lembaga Penelitian Pengembangan Keislaman, Volume 8 No. 1,

Margiantari, Heru Basuki, dan Mentari Ayu Ningsih, "Kecemasan terhadap Kehamilanpada Wanita Dewasa Muda yang Bekerja", Jurnal Universitas Gunadarma, t.th.

McCullough, M E,\& Emmons R.A \& Tsang, (2002) J.A., The Gateful Disposition:
A Conceptual And Empirical Topography, Journal Of Personality And Social Psychology Volume 82. No 1.

Munawwir, Ahmad Warson Al.(1984) Kamus al-Munawwir Arab Indonesia. Surabaya: Pustaka Progresif,

Musawi, Khalil (2011). Al. Kaifa Tabni Syakhshiyyatan, Terj. Ahmad Subandi dengan judul Terapi Akhlak. Jakarta: PT. Ufuk Publishing House.

Muthahhari, Murthada.(200) Asyna'i Ba Quran, Terj. Jawad Bafaqih dengan judul Pelajaran-Pelajaran Penting dari Alquran. Jakarta: Lentera.

Nawaei, Hadari.(2012) Metode Penelitian Bidang sosial. Yogyakarta: Gadjah Mada University Press.

O'kelly, Lawrence I.(1949) Introduction to Psychopathology. New York: PrenticeHall Inc.

Purwanto. (2010). Metode Penelitian Kuantitatif: untuk Psikologi dan Pendidikan. Yogyakarta: Pustaka Pelajar.

Pusat Kesehatan Masyarakat Kayu Tangi. (2015) Laporan Tahunan Puskesmas Kayu Tangi Tahun 2015. Banjarmasin: Puskesmas Kayu Tangi.

Pusat Kesehatan Masyarakat Pekapuran Raya (2015). Laporan Tahunan Puskesmas Pekapuran Raya TTahun 2015. Banjarmasin: Puskesmas Pekapuran Raya.

Pusat Kesehatan Masyarakat S. Parman. (2015) Laporan Tahunan Puskesmas S. Parman Tahun 2015. Banjarmasin: Puskesmas S. Parman.

Pusat Kesehatan Masyarakat Sie Mesa (2015). Laporan Tahunan Puskesmas Sie Mesa Tahun 2015. Banjarmasin: Puskesmas Sie Mesa,

Pusat Kesehatan Masyarakat Sungai Bilu (2015). Laporan Tahunan Puskesmas Sungai Bilu Tahun 2015. Banjarmasin: Puskesmas Sungai Bilu,

Pusat Kesehatan Masyarakat Terminal. (2015) Laporan Tahunan Puskesmas Terminal Tahun 2015. Banjarmasin: Puskesmas Terminal. 
Qasim, A. Kriteria Keimanan: Barometer Pribadi Insan. Bandung: Trigenda Karya, 1994.

Qurthubi, (2008). Al. Tafsir al-Qurthubi. Terj. Muhyiddin Masridha. Jakarta: Pustaka Izzam,

Rahayu, lin Tri. (2009). Psikoterapi: Perspektif Islam dan Psikologi Kontemporer. Malang: UIN Malang Press,

Sarjono, Haryadi dan Winda Julianita.(2011) SPSS vs Lisrel, Sebuah Pengantar Aplikasi Untuk Riset. Jakara: Penerbit Salemba,

Shihab, Muhammad Quraish. (2002) Tafsir al-Misbah: Peran Kesan dan Keserasian al Quran. Jakarta: Lentera Hati,

Sobur, Alex.(2003) Psikologi Umum dalam Lintas Sejarah. Bandung: Pustaka Setia,

Sugiono. Statistik untuk Penelitian (2013). Bandung: Alfabeta,

Susanti, Ni Nengah. Psikologi Kehamilan. tt:
Buku Kedokteran, t.th.

Syaifullah, Ahmad. (2011) "Pola Interaksi Sosial dan Keberagamaan Mahasiswa Gay (Studi kasus di kota Banjarmasin)". Skripsi tidak diterbitkan Fakultas Ushuluddin dan Humaniora IAIN Antasari Banjarmasin, .

Winarsunu, Tulus. (2006) Statistik dalam Penelitian Psikologi dan Pendidikan. Malang: UMM Press,

Wood, Alex M. At all. (2008)"The role of gratitude in the development of social support, stress, and depression: Two longitudinal studies", Journal of Research in Personality 42,

Ya'kub, Hamzah (1994). Tingkat Ketenangan dan Kebahagiaan Mukmin. Jakarta: Atisa,

Yunus, Mahmud. (1972) Kamus ArabIndonesia. Jakarta: Hidakarya Agung,

Zahrani, Az Musfir bin Said (2005). Konseling Terapi. terj. Sari Narulita dan Miftakhul Jannah. Jakarta: Gema Insani, Cet. I 